\title{
Struktur Komunitas Plankton di Perairan Pesisir Bukit Piatu - Kijang, Kabupaten Bintan
}

\author{
The structure of the plankton community in the coastal waters Bukit Piatu - Kijang, \\ Bintan Regency
}

\author{
Lani Puspita \\ Program Studi Pendidikan Biologi Universitas Riau Kepulauan \\ Koresponden: puspita.lani@gmail.com
}

\begin{abstract}
Abstrak
Bukit Piatu - Kijang merupakan salah satu daerah di Kabupaten Bintan yang dibuka untuk kegiatan pertambangan. Penelitian ini bertujuan untuk mengetahui struktur komunitas fitoplankton dan zooplankton di perairan Bukit Piatu - Kijang, Kabupaten Bintan, yang meliputi keanekaragaman jenis, keseragaman jenis, dan dominansi jenis. Hasil penelitian ini diharapkan dapat menjadi informasi bermanfaat untuk menduga produktivitas perairan setempat dan menduga pengaruh kegiatan pertambangan terhadap komunitas biota laut. Secara keseluruhan dapat disimpulkan bahwa ditinjau dari struktur komunitas planktonnya, produktivitas perairan di sekitar DUKS pertambangan batu granit di Bukit Piatu - Kijang ini cukup baik, dimana fitoplankton dari kelompok Bacillariophyceae ditemukan dalam jumlah yang cukup melimpah. Nilai Indeks Keanekaragaman Jenis fitoplankton dan zooplankton menunjukkan bahwa komunitas plankton berada pada kondisi sedang/moderat yang mudah berubah dengan berubahnya kondisi lingkungan perairan. Walaupun demikian, jumlah individu antar spesies relatif seragam dan tidak ada spesies yang mendominasi.
\end{abstract}

Kata kunci: Struktur komunitas, plankton, Bintan

\begin{abstract}
Bukit Piatu - Kijang is one of the areas in Bintan Regency opened for mining activities. This study aims to determine the structure of phytoplankton and zooplankton communities in Bukit Piatu - Kijang waters, Bintan regency, which includes species diversity, species uniformity, and species dominance. The results of this study are expected to be useful information to predict the productivity of local waters and suspect the effect of mining activities on marine biota community. Overall, it can be concluded that in terms of the structure of its plankton community, the productivity of the waters around DUKS granite stone mining in Bukit Piatu - Kijang is quite good, where the phytoplankton of the Bacillariophyceae group is found in abundant amounts. Diversity Index Values of phytoplankton and zooplankton indicate that plankton communities are in moderate/moderate conditions that are volatile with changes in the aquatic environment. However, the number of individuals between species is relatively uniform and no species predominate.
\end{abstract}

Keywords: Community structure, plankton, Bintan

\section{PENDAHULUAN}

Bukit Piatu - Kijang merupakan salah satu daerah di Kabupaten Bintan yang dibuka untuk kegiatan pertambangan. Pada daerah ini terdapat pertambangan batu granit seluas $25 \mathrm{Ha}$ dan pertambangan bauksit. Kegiatan pertambangan ini berpotensi menurunkan kualitas air laut di perairan sekitarnya karena sebagian areal kegiatannya mencakup daerah pesisir. 
Aktivitas kegiatan pertambangan yang berpotensi menurunkan kualitas air laut adalah: a). Operasional Dermaga Untuk Kepentingan Sendiri (DUKS) pada masing-masing perusahaan tambang bagi pengangkutan logistik dan hasil tambangnya. Aktivitas kapal dan erosi dari bahan tambang yang ditimbun di stockpile dermaga dapat menurunkan kualitas air laut. b). Pembukaan areal pertambangan yang dapat menimbulkan erosi. Partikel tanah dan lumpur yang tererosi pada akhirnya terbawa oleh aliran air hujan ke perairan pesisir, dan c). Pencucian bijih bauksit kotor yang menghasilkan material lumpur (tailing). Perusahaan pertambangan umumnya tidak membangun kolam sedimentasi tailing pada lokasi yang tepat atau bila dibangun pun kapasitasnya kurang memadai, sehingga tailing dapat melimpas ke perairan pesisir.

Penurunan kualitas air laut pada akhirnya akan mempengaruhi keberadaan biota laut di dalamnya. Salah satu komunitas biota laut yang terkena dampak penurunan kualitas air laut adalah plankton. Pada penelitian ini dilakukan pengamatan struktur komunitas fitoplankton dan zooplankton di perairan Bukit Piatu - Kijang. Lokasi pengambilan sampel plankton dilakukan di dekat pertambangan batu granit dan bauksit. Hasil penelitian mengenai struktur komunitas plankton ini diharapkan dapat memberikan gambaran mengenai produktivitas perairan setempat yang saat ini diduga terkontaminasi oleh kegiatan pertambangan di sekitarnya.

Penelitian ini bertujuan untuk mengetahui struktur komunitas fitoplankton dan zooplankton di perairan Bukit Piatu - Kijang, Kabupaten Bintan, yang meliputi keanekaragaman jenis, keseragaman jenis, dan dominansi jenis. Hasil penelitian ini diharapkan dapat menjadi informasi bermanfaat untuk menduga produktivitas perairan setempat dan menduga pengaruh kegiatan pertambangan terhadap komunitas biota laut.

\section{METODE PENELITIAN}

\section{Tempat dan Waktu}

Pengambilan sampel plankton dilakukan di perairan sekitar DUKS sebuah perusahaan tambang batu granit di Bukit Piatu - Kijang, Kabupaten Bintan. Pengambilan sampel dilakukan di dua stasiun pengamatan, yaitu: (1) sekitar 300 meter dari pinggir pantai dan (2) sekitar 5 meter dari pinggir pantai. Pengambilan sampel dilaksanakan pada tanggal 9 Februari 2009, sekitar pukul 15.00 WIB. Kondisi cuaca pada saat pengambilan sampel adalah cerah. 
Identifikasi jenis fitoplankton dan zooplankton dilakukan di Laboratorium Pakan Alami, Balai Budidaya Laut Batam, pada tanggal 10 - 17 Februari 2009.
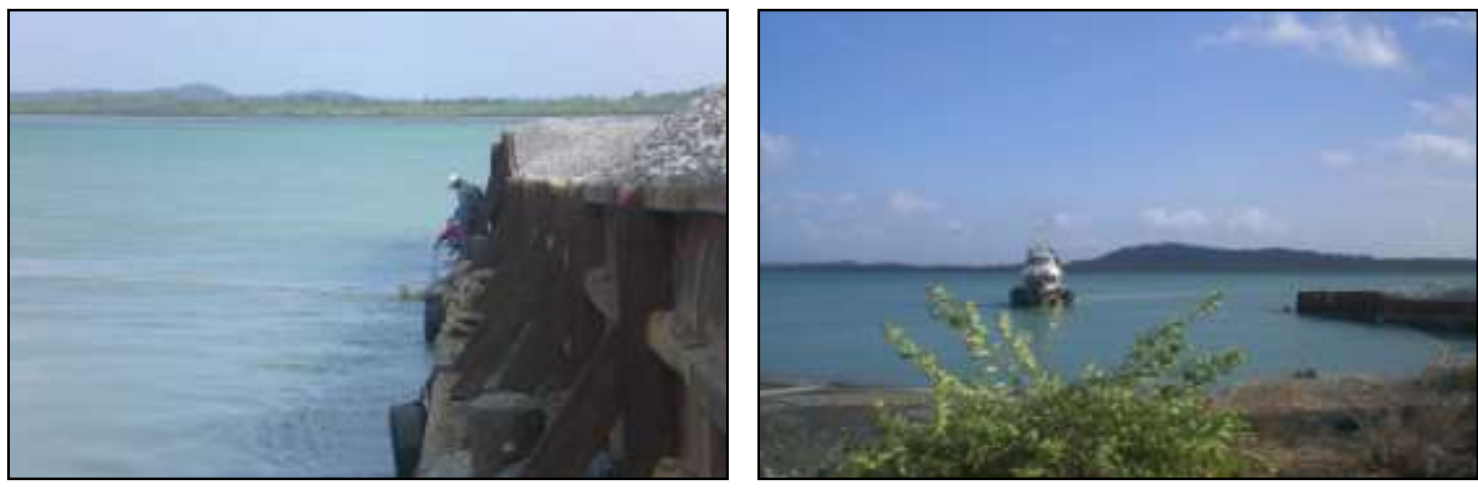

Gambar 1. Lokasi Pengambilan Sampel Plankton

\section{Alat dan Bahan}

Peralatan yang digunakan pada studi ini meliputi: plankton-net dengan mesh size 20 $\mu \mathrm{m}$, botol sampel plankton bervolume $10 \mathrm{ml}$, gelas ukur bervolume 11 , mikroskop, gelas preparat, pipet tetes, cool box, lemari pendingin, tissue, buku identifikasi, dan handy-counter. Sedangkan bahan yang digunakan pada studi ini adalah es, lugol 10\%, dan aquades.

\section{Metode Pengambilan Sampel}

Pengambilan sampel plankton dilakukan dengan menyaring 20 liter air laut menggunakan plankton-net. Agar volume air sungai yang disaring tepat 20 liter, digunakan gelas ukur bervolume 1 liter. Pengambilan sampel dilakukan secara komposit horizontal di permukaan perairan. Sampel plankton yang terkumpul pada botol sampel kemudian diawetkan dengan larutan lugol 10\% dan disimpan pada cool box. Sampel plankton yang telah diawetkan kemudian dibawa ke laboratorium untuk diidentifikasi dan dihitung kelimpahannya.

\section{Metode Analisa Sampel}

Analisa sampel fitoplankton dan zooplankton di laboratorium dilakukan dengan pengamatan di bawah mikroskop. Pengamatan di bawah mikroskop ini dilakukan untuk mengidentifikasi jenis fitoplankton dan zooplankton serta mengetahui jumlah individu masing-masing jenis fitoplankton dan zooplankton. Dengan mengetahui jenis dan jumlah individu masing-masing jenis, kita kemudian dapat menghitung kelimpahan jenis, keanekaragaman jenis, keseragamanan jenis, dan dominansi jenis. 
Pengamatan fitoplankton dan zooplankton di bawah mikroskop dilakukan dengan tahapan berikut: (1) mengocok air sampel plankton dalam botol sampel agar homogen, (2) mengambil air sampel dari botol sampel dengan pipet tetes untuk kemudian diteteskan pada preparate glass, (3) mengatur perbesaran mikroskop sehingga morfologi plankton dapat terlihat dengan jelas, (4) membandingkan morfolologi plankton yang teramati di bawah mikroskop dengan buku identifikasi plankton yang dirujuk untuk menentukan jenisnya. Dalam mengidentifikasi plankton digunakan buku panduan "The Illustrations of Marine Plankton of Japan" (Yamaji, 1979).

Pengamatan fitoplankton dan zooplankton dilakukan dengan metode sapuan, yaitu mengamati seluruh fitoplankton dan zooplankton yang ada di preparate glass. Perhitungan kelimpahan jenis fitoplankton dan zooplankton dengan metode sapuan adalah sebagai berikut:

$$
\begin{aligned}
& N_{i}=\frac{n_{i}}{V_{o}} \times \frac{V_{r}}{V_{s}} \\
& \mathrm{~N}_{\mathrm{i}}=\text { kelimpahan plankton jenis ke-i (individu/liter) } \\
& \mathrm{n}_{\mathrm{i}}=\text { jumlah total individu plankton jenis ke-i yang teramati } \\
& \text { (individu) } \\
& \mathrm{Vr}=\text { volume air contoh hasil saringan dalam botol sampel (ml), } \\
& \text { yaitu } 10 \mathrm{ml} \text {. } \\
& \text { Vo = volume air contoh yang diamati di bawah mikroskop (ml), } \\
& \text { yaitu volume satu tetes air contoh }(0,05 \mathrm{ml}) \times \text { jumlah tetes } \\
& \text { yang diamati } \\
& \mathrm{Vs}=\text { volume air yang disaring oleh plankton-net (Iiter), } \\
& \text { yaitu } 20 \text { liter. }
\end{aligned}
$$

Setelah didapatkan kelimpahan masing-masing jenis plankton, dilakukan analisa terhadap struktur komunitasnya, yang meliputi keanekaragaman jenis, keseragaman jenis, dan dominansi jenis (Basmi, 2000; Odum, 1997).

\section{$\underline{\text { Keanekaragaman Jenis }}$}

Keanekaragaman jenis dihitung dengan menghitung Indeks Keanekaragaman Jenis Shannon - Wienner (H'). Rumusnya adalah sebagai berikut:

$$
H^{\prime}=\sum\left(\frac{N_{i}}{N_{\text {total }}} \bullet \ln \frac{N_{i}}{N_{\text {total }}}\right)
$$

$\mathrm{H}^{\prime} \quad=$ Indeks Keanekaragaman Jenis Shannon - Wienner

$\mathrm{N}_{\mathrm{i}}=$ kelimpahan plankton jenis ke-i (individu/liter)

$\mathrm{N}_{\text {total }}=$ kelimpahan seluruh jenis plankton yang teridentifikasi (individu/liter)

$\ln =$ logaritma natural 
Kisaran nilai:

$$
\begin{array}{ll}
0 \leq \mathrm{H}^{\prime}<1 & \text { tingkat keanekaragaman jenis rendah } \\
1 \leq \mathrm{H}^{\prime}<3 & \text { tingkat keanekaragaman jenis sedang } \\
\mathrm{H}^{\prime} \geq 3 & \text { tingkat keanekaragaman jenis tinggi }
\end{array}
$$

$\underline{\text { Keseragaman Jenis }}$

Keseragaman jenis dihitung dengan menghitung Indeks Keseragaman Jenis Evenness (E). Rumusnya adalah sebagai berikut:

$$
E=\frac{H^{\prime}}{\ln S}
$$

$\mathrm{E} \quad=$ Indeks Keseragaman Evenness

$\mathrm{H}^{\prime}=$ Indeks keanekaragaman Shannon - Wienner

$\ln =$ logaritma natural

Kisaran nilai:

$\mathrm{S} \quad=$ jumlah species plankton yang ditemukan

$$
\begin{array}{ll}
0 \leq \mathrm{E}<0,3 & \text { tingkat keseragaman jenis rendah } \\
0,3 \leq \mathrm{E}<0,6 & \text { tingkat keseragaman jenis sedang } \\
\mathrm{E} \geq 0,6 & \text { tingkat keseragaman jenis tinggi }
\end{array}
$$

$\underline{\text { Dominansi Jenis }}$

Dominansi jenis dihitung dengan menghitung Indeks Dominansi Simpson. Rumusnya adalah sebagai berikut:

$$
D=\sum\left(\frac{N_{i}}{N_{\text {total }}}\right)^{2}
$$

$\mathrm{D}=$ indeks dominansi simpson

$\mathrm{N}_{\mathrm{i}}=$ kelimpahan plankton jenis ke-i (individu/liter)

$\mathrm{N}_{\text {total }}=$ kelimpahan seluruh jenis plankton yang teridentifikasi (individu/liter)

Kisaran nilai:

$$
\begin{array}{ll}
0 \leq \mathrm{D}<0,3 & \text { tingkat dominansi jenis rendah } \\
0,3 \leq \mathrm{D}<0,6 & \text { tingkat dominansi jenis sedang } \\
\mathrm{D} \geq 0,6 & \text { tingkat dominansi jenis tinggi }
\end{array}
$$

\section{HASIL DAN PEMBAHASAN}

Hasil perhitungan kelimpahan dan indeks struktur komunitas fitoplankton disajikan pada Tabel 1, sedangkan hasil perhitungan untuk zooplankton disajikan pada Tabel 2. Pengambilan sampel plankton dilakukan di perairan sekitar DUKS pertambangan batu granit; Stasiun 1 terletak \pm 300 meter dari pinggir pantai, sedangkan Stasiun 2 terletak \pm 5 meter dari pinggir pantai. Pada Tabel 1 dapat dilihat bahwa jenis-jenis fitoplankton pada Stasiun 1 
terdiri dari 2 kelas, yaitu Bacillariophyceae dan Ciliata; sedangkan pada Stasiun 2 terdiri dari 4 kelas, yaitu Bacillariophyceae, Cyanophyta, Ciliata, dan Sarcodina.

Tabel 1. Kelimpahan dan Struktur Komunitas Fitoplankton

\begin{tabular}{|c|c|c|c|}
\hline \multirow{2}{*}{ NO } & \multirow{2}{*}{ SPESIES } & \multicolumn{2}{|c|}{ KELIMPAHAN (Individu/liter) } \\
\hline & & STASIUN 1 & STASIUN 2 \\
\hline & BACILLARIOPHYCEAE & & \\
\hline 1 & Thalassiosira sp. & 400 & 750 \\
\hline 2 & Coscinodiscus sp. & 250 & 1000 \\
\hline 3 & Ethmodiscus gazellae & 150 & 50 \\
\hline 4 & Leptocylindris sp. & - & 100 \\
\hline 5 & Asterolampia sp. & - & 100 \\
\hline 6 & Rhizosolenia sp. & 400 & 1600 \\
\hline 7 & Bacteriastrum sp. & 150 & 500 \\
\hline 8 & Chaetoceros sp. & 450 & 3100 \\
\hline 9 & Biddulphia sp. & 200 & 450 \\
\hline 10 & Triceratium sp. & 50 & 300 \\
\hline 11 & Hemialus sp. & 50 & - \\
\hline 12 & Climacodium sp. & - & 200 \\
\hline 13 & Flagilaria sp. & 100 & 300 \\
\hline 14 & Asterionella sp. & - & 50 \\
\hline 15 & Thalassionema nitzschioides & 150 & 600 \\
\hline 16 & Thalassiotrix sp. & 200 & 800 \\
\hline 17 & Rhabdonema sp. & 50 & 100 \\
\hline 18 & Cocconeis sp. & - & 100 \\
\hline 19 & Navicula sp. & - & 150 \\
\hline 20 & Pleurosigma sp. & 250 & 750 \\
\hline 21 & Nitzschia sp. & 400 & 1550 \\
\hline 22 & Amphiprora sp. & 100 & - \\
\hline 23 & Campylediscus sp. & 50 & - \\
\hline 24 & Gamphonema sp. & 50 & 50 \\
\hline 25 & Climacosphenia sp. & - & 150 \\
\hline 26 & Bacillaria sp. & - & 250 \\
\hline 27 & Rhoicosphenia sp. & - & 50 \\
\hline 28 & $\begin{array}{l}\text { Cerratium sp. } \\
\text { CYANOPHYTA }\end{array}$ & 50 & - \\
\hline 29 & $\begin{array}{l}\text { Trichodesmium sp. } \\
\text { CILIATA }\end{array}$ & - & 50 \\
\hline 30 & Leprotintinnus sp. & - & 400 \\
\hline 31 & Tintinnopsis sp. & 100 & 300 \\
\hline 32 & $\begin{array}{l}\text { Eutintinnus sp. } \\
\text { SARCODINA }\end{array}$ & 100 & - \\
\hline 33 & Globigerina sp. & - & 100 \\
\hline 34 & Globorotalia sp. & - & 200 \\
\hline & Jumlah Individu & 3700 & 14100 \\
\hline & Jumlah Taxa & 21 & 29 \\
\hline & Indeks Keanekaragaman (H') & 2,7865 & 2,7592 \\
\hline & Indeks Keseragaman (E) & 0,9153 & 0,8194 \\
\hline & Indeks Dominansi (D) & $\mathbf{0 , 0 7 3 8}$ & $\mathbf{0 , 0 9 4 7}$ \\
\hline
\end{tabular}

Keterangan: Stasiun 1 : Perairan sekitar DUKS, 300 meter dari pinggir pantai

Stasiun 2 : Perairan sekitar DUKS, 5 meter dari pinggir pantai 
Pada stasiun 1 dan 2 tersebut, sebagian besar spesies plankton berasal dari Kelas Bacillariophyceae. Menurut Nybakken (1992), fitoplankton berukuran besar yang tertangkap oleh jaring plankton terdiri dari dua kelompok besar, yaitu Diatom (Bacillariophyceae) dan Dinoflagellata. Diatom adalah komponen utama dalam komunitas plankton, yang mana kehidupan laut tergantung padanya (Microsoft Encarta, 2008). Mendominasinya jenis-jenis fitoplankton dari kelompok Bacillariophyceae merupakan salah satu tanda baiknya produktivitas perairan.

Kelimpahan total fitoplankton pada Stasiun 2 jauh lebih tinggi daripada Stasiun 1. Kelimpahan total fitoplankton pada Stasiun 2 adalah 14.100 individu/liter, sedangkan pada Stasiun 1 berjumlah 3.700 individu/liter, ini berarti kelimpahan total fitoplankton pada Stasiun 2 hampir 4 kali lipat dibandingkan Stasiun 1. Dari banyaknya jumlah spesies fitoplankton yang ditemukan, Stasiun 2 juga lebih banyak daripada Stasiun 1. Pada Stasiun 2 ditemukan 29 jenis spesies fitoplankton, sedangkan pada Stasiun 1 ditemukan 21 jenis spesies fitoplankton. Lebih tingginya kelimpahan fitoplankton pada Stasiun 2 diperkirakan karena stasiun ini terletak lebih dekat dengan pantai sehingga masukkan nutrien ke perairan lebih tinggi daripada Stasiun 1. Menurut Nybakken (1992), sejumlah besar unsur hara (N dan P) berasal dari daratan melalui run-off. Walaupun jumlah kelimpahan total fitoplanktonnya jauh berbeda, struktur komunitas fitoplankton antara Stasiun 1 dan 2 kurang lebih serupa, hal ini terlihat dari nilai Indeks Keanekaragamanan, Keseragamanan, dan Dominansi Jenisnya yang tidak jauh berbeda.

Di kedua stasiun pengamatan, keanekaragaman jenis fitoplankton tergolong sedang (nilai indeks berada pada kisaran 1 - 3). Pada komunitas dengan keanekaragaman jenis sedang (moderat), komunitas fitoplankton mudah berubah hanya dengan mengalami perubahan lingkungan yang relatif kecil. Apabila terjadi peningkatan konsentrasi polutan, maka akan terjadi perubahan struktur komunitas yang ekstrim yang mengarah kepada Indeks Keanekaragaman yang rendah $\left(H^{\prime}<1\right)$. Sebaliknya, apabila jumlah polutan yang masuk ke dalam perairan sedikit, jumlah nutrien mencukupi, dan intensitas penyinaran matahari mencukupi, maka nilai Indeks Keanekaragaman Jenis dapat lebih tinggi dari semula (Basmi, 2000). Nilai Indeks Keanekaragaman pada Stasiun 1 adalah 2,7865 sedangkan pada Stasiun 2 adalah 2,7592; angka-angka ini menunjukkan bahwa walaupun masih tergolong dalam keanekaragaman jenis yang sedang, nilai-nilainya sudah hampir mengarah pada keanekaragaman jenis yang tinggi. 
Dilihat pada nilai Indeks Keseragaman Jenisnya, kedua stasiun yang diamati memiliki keseragaman jenis fitoplankton yang tinggi (nilai indeks berada pada kisaran 0,6 sampai 1). Nilai Indeks Keseragaman Jenis yang tinggi menunjukkan bahwa komunitas fitoplankton berada dalam kondisi yang stabil, dimana jumlah spesies antar individu relatif sama dan tidak ada spesies yang mendominansi (Basmi, 2000; Odum 1998). Kestabilan komunitas fitoplankton ini juga sejalan dengan hasil perhitungan Indeks Dominansi Jenis, dimana pada kedua stasiun nilai Indeks Dominansi Jenis tergolong rendah (nilai indeks lebih kecil dari $0,4)$.

Tabel 2. Kelimpahan dan Struktur Komunitas Zooplankton

\begin{tabular}{|c|c|c|c|}
\hline \multirow{2}{*}{ NO } & \multirow{2}{*}{ SPESIES } & \multicolumn{2}{|c|}{ KELIMPAHAN (Individu/liter) } \\
\hline & & STASIUN 1 & STASIUN 2 \\
\hline & CRUSTACEA & & \\
\hline 1 & Calanidae & & 100 \\
\hline 2 & Acartia sp. & 100 & 250 \\
\hline 3 & Trigiopus sp. & & 100 \\
\hline 4 & Sacculina sp. (nauplius) & & 100 \\
\hline & Jumlah Individu & 100 & $\mathbf{5 5 0}$ \\
\hline & Jumlah Taxa & 1 & 4 \\
\hline & Indeks Keanekaragaman (H') & $\mathbf{0 , 0 0 0 0}$ & 1,2883 \\
\hline & Indeks Keseragaman (E) & $\mathbf{0 , 0 0 0 0}$ & 0,9293 \\
\hline & Indeks Dominansi (D) & 1,0000 & $\mathbf{0 , 3 0 5 8}$ \\
\hline
\end{tabular}

Keterangan: Stasiun 1: Perairan sekitar DUKS, 300 meter dari pinggir pantai

Stasiun 2:Perairan sekitar DUKS, 5 meter dari pinggir pantai

Pada Tabel 2 dapat kita lihat bahwa jenis-jenis zooplankton yang ditemukan di Stasiun 1 dan 2 semuanya berasal dari Kelas Crustacea. Pada Stasiun 2 ditemukan 4 jenis zooplankton, sedangkan pada Stasiun 1 hanya ditemukan 1 jenis zooplankton. Kelimpahan total zooplankton pada Stasiun 2 adalah 550 individu/liter, sedangkan pada Stasiun 1 hanya 100 individu/liter. Jumlah jenis/taxa dan kelimpahan zooplankton ini sejalan dengan kondisi fitoplankton di masing-masing stasiun pengamatan tersebut. Hal ini terjadi karena zooplankton merupakan herbivora primer di laut yang merupakan konsumen langsung dari fitoplankton (Nybakken, 1992). Banyak sedikitnya fitoplankton akan berpengaruh pada banyak sedikitnya zooplankton.

Hanya ditemukannya satu jenis zooplankton pada Stasiun 1 menyebabkan nilai Indeks Keanekaragaman Jenis menjadi minimum/sangat rendah (nilai indeks $=0$ ). Hal ini menunjukkan struktur komunitas zooplankton yang tidak stabil atau komunitas tersebut sedang mengalami gangguan (Basmi, 2000). Kondisi ini juga menyebabkan nilai Indeks Dominansi Jenis menjadi maksimum (nilai indeks $=1$ ) dan nilai Indeks Keseragaman Jenis 
menjadi minimum (nilai indeks =0). Pada Stasiun 1 ini, satu-satunya spesies yang ditemukan (yaitu Acartia sp.) adalah spesies yang mendominansi. Selain terkait dengan kelimpahan fitoplankton yang jauh lebih rendah pada Stasiun 1, sangat rendahnya keanekaragaman jenis zooplankton di Stasiun 1 juga disebabkan karena pengambilan sampel plankton dilakukan di siang hari, sedangkan pengambilan sampel ini hanya mencakup permukaan perairan. Menurut Nybakken (1992), zooplankton melalukan migrasi vertikal. Migrasi vertikal ini adalah migrasi harian yang dilakukan oleh organisme zooplankton tertentu ke arah dasar laut pada siang hari dan ke arah permukaan laut pada malam hari.

Pada Stasiun 2, stuktur komunitas zooplankton yang terbentuk lebih baik daripada Stasiun 1. Pada Stasiun 2 ini, keanekaragaman jenis zooplankton tergolong sedang/moderat (nilai indeks berada pada kisaran 1 - 3), artinya struktur komunitas zooplankton mudah berubah dengan berubahnya kondisi lingkungan. Walaupun demikian, pada Stasiun 2 jumlah individu antara spesies relatif seragam dan tidak ada yang mendominasi. Pada Stasiun 2 ini, Keseragaman Jenis tergolong tinggi (nilai indeks > 0,6) dan Dominansi Jenis tergolong rendah (nilai indeks < 0,4). Diantara keempat jenis zooplankton yang ditemukan pada Stasiun 2 ini, 3 jenis merupakan holoplankton, sedangkan 1 jenis lainnya adalah meroplankton (yaitu nauplius Sacculina sp.). Holoplankton adalah hewan yang dalam keseluruhan daur hidupnya bersifat planktonik, sedangkan meroplankton adalah hewan yang hanya dalam sebagian daur hidupnya saja yang bersifat planktonik (yaitu pada saat larva) (Nybakken, 1992).

\section{KESIMPULAN}

Secara keseluruhan dapat disimpulkan bahwa ditinjau dari struktur komunitas planktonnya, produktivitas perairan di sekitar DUKS pertambangan batu granit di Bukit Piatu - Kijang ini cukup baik, dimana fitoplankton dari kelompok Bacillariophyceae ditemukan dalam jumlah yang cukup melimpah. Nilai Indeks Keanekaragaman Jenis fitoplankton dan zooplankton menunjukkan bahwa komunitas plankton berada pada kondisi sedang/moderat yang mudah berubah dengan berubahnya kondisi lingkungan perairan. Walaupun demikian, jumlah individu antar spesies relatif seragam dan tidak ada spesies yang mendominasi. 


\section{REFERENSI}

Basmi, J. 2000. Planktonologi: Plankton sebagai Bioindikator Kualitas Perairan. Fakultas Perikanan dan Ilmu Kelautan. Institut Pertanian Bogor. Bogor.

Microsoft Encarta. 2008. Diatom. Microsoft Corporation. Redmond, WA - USA.

Nybakken, J. W. 1992. Biologi Laut: Suatu Pendekatan Ekologis. PT. Gramedia Pustaka Utama. Jakarta.

Odum, E. P. 1998. Dasar-Dasar Ekologi. Gadjah Mada University Press. Jogjakarta.

Yamaji, I. 1979. Illustrations of the Marine Plankton of Japan. Hoikusha Publishing Co., Ltd. 